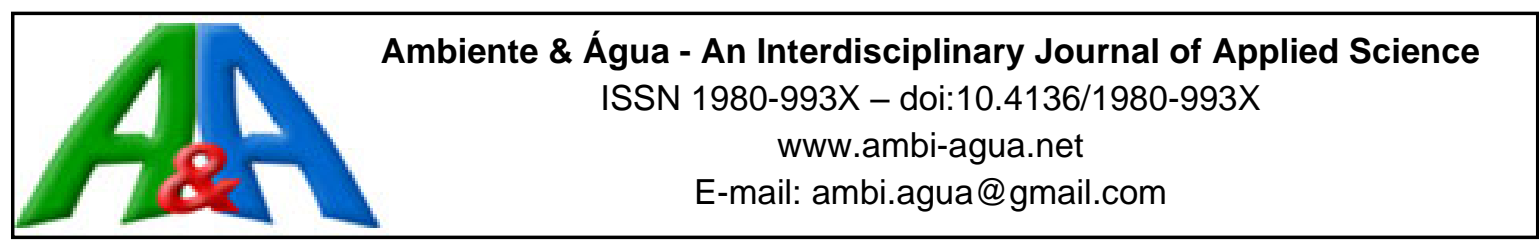

\title{
Physical-chemical and microbiological analysis of water from shallow wells in Imperatriz (MA), Brazil
}

ARTICLES doi:10.4136/ambi-agua.2538

Received: 27 Aug. 2020; Accepted: 01 Oct. 2020

\begin{abstract}
Anderson Gomes Nascimento Santana ${ }^{1 *}$; Cecilia Nahomi Kawagoe Suda1 ${ }^{10}$; Jairo Rodrigues Santana Nascimento ${ }^{2}$; Gannabathula Sree Vani ${ }^{1}$ id
\end{abstract}

${ }^{1}$ Programa de Pós-Graduação em Ciências Ambientais (PPGCA). Universidade de Taubaté (UNITAU), Estrada Municipal Doutor José Luiz Cembranelli, n5000, CEP: 12081-010, Taubaté, SP, Brazil.

E-mail: cnksuda@hotmail.com,gannabathula.vani@usf.edu.br

${ }^{2}$ Programa de Pós-graduação em Gestão e Desenvolvimento Regional. Universidade de Taubaté (UNITAU), Rua Visconde do Rio Branco, n²10, CEP: 12020-040, Taubaté, SP, Brazil. E-mail: jairo.santana@facimp.edu.br

*Corresponding author. E-mail: anderson.nascimento@ufma.br

\begin{abstract}
The quality of groundwater from Imperatriz (MA) is little known. This work investigated microbiological contaminants (total coliforms and Escherichia coli) and the levels of 10 physicochemical parameters in 10 wells located in the urban periphery of the municipality of Imperatriz. The counts of $E$. coli and total coliforms were $\geq 1600 \mathrm{CFU} \mathrm{mL}^{-1}$ in all the wells. Levels of chloride, sulfate, hardness and turbidity levels were below the maximum allowed for drinking water. However, levels of iron $\left(0.46-1.75 \mathrm{mg} \mathrm{L}^{-1}\right)$ and $\mathrm{pH}(5.02-5.92)$ were not in compliance with drinking water standards in all the wells investigated. The same was observed in relation to oil and grease in water $\left(0.0-6.8 \mathrm{mg} \mathrm{L}^{-1}\right)$, which were detected in $40 \%$ of the wells. Levels of nitrite $\left(0.71-3.84 \mathrm{mg} \mathrm{L}^{-1}\right)$, nitrate $\left(4.16-13.52 \mathrm{mg} \mathrm{L}^{-1}\right)$ and total dissolved solids $\left(810-2060 \mathrm{mg} \mathrm{L}^{-1}\right)$ were above the highest limit in $50 \%, 60 \%$ and $70 \%$ of wells, respectively. The acidic $\mathrm{pH}$ observed in all the wells makes them also unsuitable for animal intake and irrigation. The acidity and the high level of iron in all wells suggest that they are natural characteristics of the soil and the groundwater of the region. Contamination with nitrite and nitrate in some wells, as well as high counts of coliforms, may be related to deficiencies in basic sanitation in the area. The origin of oil and grease in the wells should be better investigated to avoid contamination of the water table.
\end{abstract}

Keywords: groundwater, pollution, water quality.

\section{Análise físico-química e microbiológica da água de poços rasos em Imperatriz (MA), Brasil}

\section{RESUMO}

A qualidade da água subterrânea de Imperatriz (MA) é pouco conhecida. O presente trabalho investigou os contaminantes microbiológicos (coliformes totais e Escherichia coli) e os níveis de 10 parâmetros físico-químicos em 10 poços, localizados na periferia urbana do município de Imperatriz. As contagens de E. coli e de coliformes totais foi $\geq 1600 \mathrm{UFC} \mathrm{mL}^{-1}$ em todos os poços. Os níveis de cloreto, sulfatos, dureza e turbidez estavam abaixo dos valores máximos permitidos para água potável. Entretanto, os níveis de ferro $\left(0,46-1,75 \mathrm{mg} \mathrm{L}^{-1}\right)$ e de 
pH $(5,02$ - 5,92) não estavam em conformidade com os padrões para água potável em todos os poços investigados. O mesmo foi observado em relação a óleos e graxas $\left(0,0-6,8 \mathrm{mg} \mathrm{L}^{-1}\right)$, que foram detectados em $40 \%$ dos poços. Níveis de nitrito $\left(0,71-3,84 \mathrm{mg} \mathrm{L}^{-1}\right)$, nitrato $(4,16-13,52$ $\left.\mathrm{mg} \mathrm{L}^{-1}\right)$ e sólidos totais dissolvidos $\left(810\right.$ - $\left.2060 \mathrm{mg} \mathrm{L}^{-1}\right)$ estavam acima do limite em 50\%, 60\% e $70 \%$ dos poços, respectivamente. $\mathrm{O} \mathrm{pH}$ ácido observado em todos poços torna-os inadequados também para uso em dessedentação de animais e irrigação. A acidez da água e o nível elevado de ferro em todos os poços sugerem que essas características são decorrentes da natureza do solo e do lençol freático da região. As contaminações pontuais com nitrito e nitrato podem ser decorrentes da falta de saneamento básico na área. A origem de óleos e graxas deve ser melhor investigada para evitar a contaminação do lençol freático.

Palavras-chave: água subterrânea, poluição, qualidade da água.

\section{INTRODUCTION}

Groundwater extraction dates to time immemorial, and one of the earliest records of dug wells can be found in Indian Vedic scriptures dating from 8000 BC. For a long time, this human activity did not have a significant impact on groundwater quantity and quality on a global scale. However, the use of this water has intensified since the 20th century, especially in the arid and semi-arid regions of the planet, making them productive areas with economic and social development. However, the intensive use of groundwater has caused side effects such as reduction of water quantity, which can be perceived as a decrease in water flow or even depletion of artesian wells and springs, as this activity has altered hydrological cycles. Groundwater is also contaminated by domestic pollutants that are currently much larger in quantity and diversity due to population expansion and lifestyle changes. Septic tanks, untreated sewage, open dumps and poorly designed landfills pollute soils and aquifers. Agriculture produces diffuse pollution as a result of the application of manure, fertilizers and pesticides, being the most important source of groundwater pollution. In view of this situation, during the second half of the 20th century the perception that groundwater is a finite and vulnerable resource was developed, and it became evident that its exploitation must be accompanied by management of groundwater systems (van der Gun, 2019). About $90 \%$ of Brazilian rivers are fed by the discharge of aquifers, which contributes to the base flow of watercourses, making them perennial in dry periods. Therefore, the observance of the water quality of aquifers is important not only for human consumption, but also for ecosystem preservation of rivers, lakes and swamps which are fed by aquifers. In addition, groundwater is an important alternative during periods of water scarcity that have become frequent in Brazil in recent years. Despite this, groundwater monitoring in Brazil is still incipient and, in many localities, it does not exist (ANA, 2017).

Imperatriz is a municipality in the state of Maranhão (MA) and is located in the Tocantins and Araguaia hydrographic region (Região Hidrográfica do Tocantins e Araguaia - RHTA). Because of the size of its population (about 260,000 inhabitants, IBGE, https://cidades.ibge.gov.br) it is one of the main municipalities in that hydrographic region (ANA, 2017). In the RHTA, 3,818 wells have already been registered, but it is estimated that there are many more in use, with about $98.7 \%$ of these wells being used for human consumption and $1.3 \%$ for industry. The use of groundwater for animal intake and irrigation is not widespread in the RHTA, and knowledge of the groundwater quality in this hydrographic region regarding physicochemical and bacteriological aspects is limited (ANA, 2009).

According to a survey by Correia Filho (2011), $100 \%$ of the wells in Imperatriz are tubular, with $68 \%$ public and $32 \%$ private. Most wells (42\%) are intended for urban water supply, 35\% for domestic use, $6 \%$ for industries, $4 \%$ for domestic irrigation and the remainder for various 
purposes, and well depths ranged from 8 to $457 \mathrm{~m}$. This same author reported the electrical conductivity and total dissolved solids of these wells, which ranged from 30.01 to $968.40 \mu \mathrm{S} \mathrm{cm}^{-1}$ and between 19.51 and $724.75 \mathrm{mg} \mathrm{L}^{-1}$, respectively. However, many other physicochemical parameters of water quality have been little investigated. In the records of the Groundwater Information System (Sistema de Informações de Águas Subterrâneas - SIAGAS, http://siagasweb.cprm.gov.br/layout/), there are 44 wells registered in Imperatriz (search done in August 15, 2020). Information on parameters such as water electrical conductivity, color (Pt/Co), taste, odor, temperature, turbidity, suspended and settleable solids, natural aspects and $\mathrm{pH}$ of each well can be obtained on the site of SIAGAS. However, only four records for conductivity (ranging from 94.05 to $\left.300 \mu \mathrm{S} \mathrm{cm}^{-1}\right)$, two for temperature $\left(27.0\right.$ and $28.9^{\circ} \mathrm{C}$ ), one for turbidity (1.08 NTU) and four for $\mathrm{pH}$ (ranged from 7.13 to 8.3) were found on the site of SIAGAS. Additionally, on this site there was only one description of the natural appearance, odor, and taste of water from one well, which was considered crystalline, odorless, and tasteless, respectively. Most of these records date back to the 1980s, and there was no follow-up of the evolution of the quality. Recently, Santos et al. (2020) analyzed physicochemical parameters of an artesian well in a rural area that is used for water consumption by goats and sheep. They concluded that the water quality was good because no significant quantity of contaminants was found.

This work analyzed the physicochemical and bacteriological parameters of 10 private wells located on the outskirts of the urban area of Imperatriz. The waters of these wells are used by residents for irrigation of vegetable gardens and for domestic use. The results obtained may contribute to a better knowledge of the water quality of the region's water table.

\section{MATERIAL AND METHODS}

\subsection{Location of the wells}

The wells were localized in a peripheral area of the urban zone of the municipality of Imperatriz, state of Maranhão, Brazil. The main landmark nearby is the Cemetery "Bom Jesus". The geographic coordinates of the wells (Table 1) were determined using GPS and the maps were generated using the Google Earth Pro program (Figure 1).

Table 1. Geographical coordinates of the wells.

\begin{tabular}{ccc}
\hline Wells & Latitude & Longitude \\
\hline P1 & $5^{\circ} 29^{\prime} 51.2^{\prime \prime ~ S}$ & $47^{\circ} 25^{\prime} 43.0^{\prime \prime ~ W}$ \\
P2 & $5^{\circ} 29^{\prime} 49.8^{\prime \prime ~ S}$ & $47^{\circ} 25^{\prime} 44.3^{\prime \prime} \mathrm{W}$ \\
P3 & $5^{\circ} 29^{\prime} 49.9^{\prime \prime ~ S}$ & $47^{\circ} 25^{\prime} 45.2^{\prime \prime} \mathrm{W}$ \\
P4 & $5^{\circ} 29^{\prime} 48.4^{\prime \prime} \mathrm{S}$ & $47^{\circ} 25^{\prime} 46.1^{\prime \prime} \mathrm{W}$ \\
P5 & $5^{\circ} 29^{\prime} 46.8^{\prime \prime} \mathrm{S}$ & $47^{\circ} 25^{\prime} 47.0^{\prime \prime} \mathrm{W}$ \\
P6 & $5^{\circ} 29^{\prime} 45.8^{\prime \prime ~ S}$ & $47^{\circ} 25^{\prime} 44.2^{\prime \prime} \mathrm{W}$ \\
P7 & $5^{\circ} 29^{\prime} 40.1 " \mathrm{~S}$ & $47^{\circ} 25^{\prime} 35.9^{\prime \prime} \mathrm{W}$ \\
P8 & $5^{\circ} 29^{\prime} 38.9^{\prime \prime} \mathrm{S}$ & $47^{\circ} 25^{\prime} 34.5^{\prime \prime} \mathrm{W}$ \\
P9 & $5^{\circ} 29^{\prime} 39.1^{\prime \prime ~ S}$ & $47^{\circ} 25^{\prime} 36.6^{\prime \prime} \mathrm{W}$ \\
P10 & $5^{\circ} 29^{\prime} 48.2^{\prime \prime ~ S}$ & $47^{\circ} 25^{\prime} 36.5^{\prime \prime} \mathrm{W}$ \\
\hline
\end{tabular}




\subsection{Characteristics of wells}

The depths ranged between 6 and $16 \mathrm{~m}$ and the diameters were $1.2 \mathrm{~m}$. The wells were dug by hand to capture water from the water table.

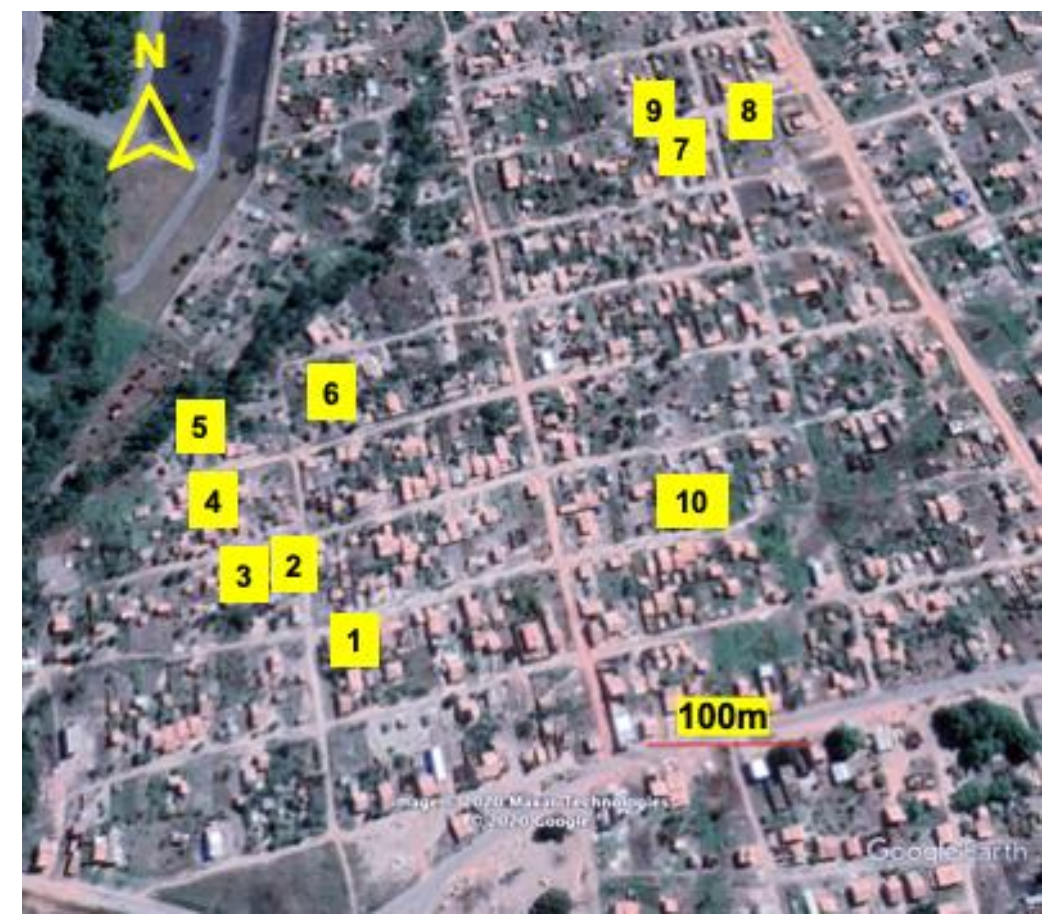

Figure 1. Location map of the wells P1 - P10, which were numbered respectively from 1 to 10 .

\subsection{Water sample collection}

The samples were collected in July 2018, at a minimum depth of 30 centimeters from the water surface and were placed in glass containers which were previously thoroughly washed and rinsed with deionized water and autoclaved. After collection, the samples were kept refrigerated $\left(5-10^{\circ} \mathrm{C}\right)$ and analyzed in triplicate within 12 hours.

\subsection{Water analysis}

Turbidity, hardness and chloride were determined according to Fundação Nacional de Saúde (2006); nitrite $\left(\mathrm{NO}_{2}-\mathrm{N}\right)$ and nitrate $\left(\mathrm{NO}_{3}-\mathrm{N}\right)$ according to NBR 12619 and NBR 12620, respectively (ABNT, 1992a; 1992b); total iron according to NBR 13934 (ABNT, 1997); oils and greases (APHA et al., 2017) and total dissolved solids (TDS) by gravimetry (ABNT, 1989) and sulfates according to Tabatabai (1974). The $\mathrm{pH}$ was measured using a pHmeter (Homis, mPA - 210P6). For total coliform and Escherichia coli counts the water samples were filtered with a membrane filter. After that the membrane was placed in contact with the culture medium (Chromocult Coliform Agar) on checkered surface Petri dishes. The plates were maintained at $35^{\circ} \mathrm{C}$ for 24 hours. Then, counts of E. coli (blue colonies) and total coliforms (Klebsiella, Enterobacter and Citrobacter) that formed pink/lilac colonies were done. All analyses were performed at the Water Analysis Laboratory of the State University of Maranhão (UEMA).

\section{RESULTS AND DISCUSSION}

In all analyzed wells, levels of chloride, sulfate, hardness, and turbidity were within the permitted values for drinking water (Brasil, 2017) (Table 2). The low level of salinity is a characteristic of RHTA groundwater (ANA, 2009). However, the $\mathrm{pH}$ was below the recommended lower limit in all wells, presenting values between 5.02 and 5.92 (Table 2). The 
pH of well waters are often below 6.0 in different localities in the state of Maranhão, such as in Raposa, São Luís, Timbiras, Paço Lumiar, Santa Helena and Itapecuru-Mirim, and in Santa Helena a pH of 3.8 was observed (Alves, 2010; Coelho et al., 2017; de Oliveira et al., 2019; Marques et al., 2010; Oliveira, 2018; Rodrigues et al., 2020). In the rural area of Imperatriz, an artesian well with pH 6.0 was found, which is at the lower limit of the reference value (Santos et al., 2020).

Table 2. Physicochemical parameters of water from different wells (P1 - P10) located in the municipality of Imperatriz.

\begin{tabular}{ccccccc}
\hline & Chloride & Sulfates & Hardness & Turbidity & & Total iron \\
\cline { 1 - 2 } \cline { 1 - 1 } & $\left(\mathrm{mg} \mathrm{L}^{-1}\right)$ & $\left(\mathrm{mg} \mathrm{L}^{-1}\right)$ & $\left(\mathrm{mg} \mathrm{L}^{-1}\right)$ & $(\mathrm{NTU})$ & & $\left(\mathrm{mg} \mathrm{L}^{-1}\right)$ \\
\hline P1 & 11.08 & 14.55 & 93.21 & 2.45 & 5.11 & 1.03 \\
P2 & 8.44 & 29.04 & 88.79 & 1.86 & 5.54 & 0.99 \\
P3 & 16.08 & 18.77 & 91.04 & 1.51 & 5.92 & 0.75 \\
P4 & 6.28 & 32.27 & 52.11 & 1.11 & 5.54 & 0.7 \\
P5 & 9.33 & 41.04 & 77.48 & 0.91 & 5.88 & 0.81 \\
P6 & 14.55 & 27.58 & 66.21 & 1.09 & 5.09 & 0.46 \\
P7 & 4.65 & 51.04 & 50.99 & 1.88 & 5.03 & 1.02 \\
P8 & 3.11 & 66.66 & 48.44 & 1.37 & 5.10 & 0.80 \\
P9 & 5.52 & 66.66 & 42.64 & 1.92 & 5.87 & 0.66 \\
P10 & 21.25 & 81.00 & 86.09 & 2.70 & 5.02 & 1.75 \\
MAL & 250.00 & 250.00 & 500 & 5.00 & $6.0-9.5$ & 0.30 \\
\hline
\end{tabular}

$\mathrm{MAL}=$ maximum allowable level/reference range (Brasil, 2017).

In all wells, the total iron concentration was higher than the maximum recommended value of $0.3 \mathrm{mg} \mathrm{L}^{-1}$ (Brasil, 2017) (Table 2). Although this element is not considered harmful to health in the concentrations normally found in natural waters, it can cause aesthetic problems (stains on clothes or sanitary utensils), in addition to an unpleasant taste and odor of the water. It may also favor the growth of iron bacteria that form dark-colored slime layers inside pipes. The sludge that is formed can be released into the water network due to fluctuations in the flow, leading to the presence of clogs along the pipeline. The presence of iron in groundwater may be caused by dissolution of rocks that come into contact with infiltrated water (Ityel, 2011). In soils experimentally maintained to be in contact with water, iron solubility gradually increased with a decrease in $\mathrm{pH}$ to values below 6.0 (Tack et al., 1996). It was also found that iron concentration is higher in groundwater with low $\mathrm{pH}$ compared to higher $\mathrm{pH}$ waters (Ibrahim, 2016). Therefore, it is possible that the high iron contents in the soil of the Imperatriz region (ANA, 2009; Costa Neto et al., 2014) and the acidity of the water have contributed to high levels of iron in the water of investigated wells.

Oils and greases were detected in wells P1, P3, P4 and P10 (Figure 2); despite the proximity between wells P2 and P3 (Figure 1), P2 did not present these contaminants. The same occurred with wells P4 and P5, because P4 presented oils and greases while P5 did not. The presence of oils and greases is often associated with leaks of fuels such as diesel oil from underground tanks at gas stations, oil pipeline disruption, or near oil refineries (Abdanur and Nolasco, 2005; de Oliveira and Loureiro, 1998). However, such facilities were not found in the vicinity of the wells in the current study. Car repair shops could also contribute to this type of contamination, but the origin of these contaminants could not be identified. 


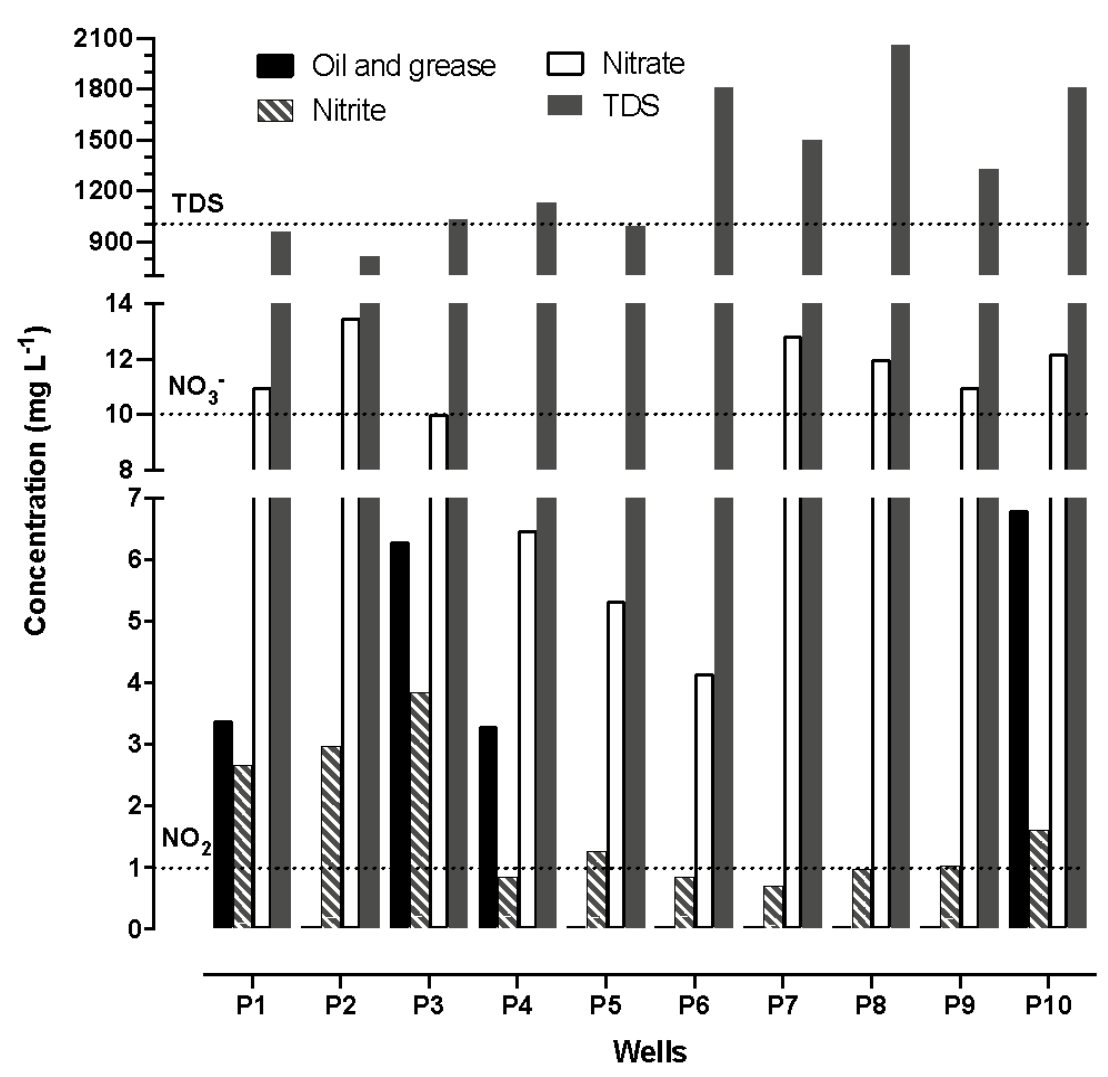

Figure 2. Concentration of oil and greases, nitrate, nitrite and total dissolved solids (TDS) in the water of different wells (P1 - P10) located in the municipality of Imperatriz. The dotted lines indicate the maximum allowable values of nitrite $\left(\mathrm{NO}_{2}^{-}, 1 \mathrm{mg} \mathrm{L}^{-1}\right)$, nitrate $\left(\mathrm{NO}_{3}^{-}\right.$, $\left.10 \mathrm{mg} \mathrm{L}^{-1}\right)$ and TDS (1000 $\left.\mathrm{m} \mathrm{L}^{-1}\right)$ in drinking water, according to Brazil (2017). Oils and greases should be absent in Class 1, 2 and 3 freshwater (Conama, 2005).

In wells P1, P2, P3, P5 and P10, nitrite levels were above the established limit (Figure 2). The same occurred with nitrate in P1, P2, P7, P8, P9 and P10. Therefore, 50\% and $60 \%$ of the wells presented inadequate levels of nitrite and nitrate, respectively. Nitrite is an intermediary of biochemical pathways involving redox reactions such as nitrification and denitrification. These reactions occur in soil or water and are carried out by bacteria. Nitrification involves the production of nitrite from ammonia followed by the conversion of nitrite into nitrate. Denitrification involves the conversion of both nitrite and nitrate to atmospheric nitrogen $\left(\mathrm{N}_{2}\right)$. Not all denitrifying microorganisms are able to perform all the reactions of the pathway, as they do not express some enzymes necessary for the process. Therefore, nitrite may accumulate if an environmental condition selects only microorganisms that convert nitrate into nitrite, to the detriment of others. The presence of inhibitors of a specific denitrification enzyme, nitrite reductase, can also lead to nitrite accumulation. This enzyme may be inhibited by increased nitrate concentration (Philips et al., 2002).

There is a belief that shallow wells are more prone to contamination by pollutants, including nitrate. However, this does not always occur. Shallow groundwater is often associated with poorly drained soils and anaerobic status. Under these conditions, nitrate denitrification may occur in the presence of organic carbon and denitrifying bacteria. Therefore, nitrate removal of these waters up to $5 \mathrm{~m}$ deep may occur if the environment is reducing. Iron levels observed in the present study may be associated with a reducing environment (Sacchi et al., 2013). Thus, it is possible that nitrate levels may be higher than the observed ones, but they are 
maintained at that level because of denitrification. However, further studies are needed to confirm this hypothesis.

Ingested nitrate can be reduced to nitrite by mouth bacteria and in children's stomachs, because the gastric $\mathrm{pH}$ of infants is less acidic than that in older children and adults. This favors proliferation of intestinal flora that can reduce the ingested nitrate to nitrite. Nitrite causes the conversion of hemoglobin to methemoglobin in the bloodstream interfering with oxygen transportation in the body, a condition known as methemoglobinemia. The intake of water containing nitrate by pregnant women has been correlated with abortions and congenital malformations of the nervous system. Nitrite and nitrate can react with secondary amines and amides from the diet in the stomach and produce carcinogenic $\mathrm{N}$-nitrosamines and $\mathrm{N}$ nitrosamides. High nitrate levels in water have also been correlated with hypothyroidism in women (Ward et al., 2018).

High nitrate level in groundwater is not a rare phenomenon. In the USA, it was estimated that $21 \%$ of private wells in rural areas have levels above the established limit (Ward et al., 2018). In northeastern China, $32 \%$ of wells exceeded the established limit, which is $20 \mathrm{mg} \mathrm{L}^{-1}$ of $\mathrm{NO}_{3}-\mathrm{N}$ in that country (Zhai et al., 2017). In both cases, excessive use of nitrogen fertilizers was considered as the cause of nitrate contamination.

According to the report of the National Water Agency of Brazil (Agência Nacional de Águas - ANA), nitrate levels may be high in RHTA wells probably because of deficiency in basic sanitation, with presence of cesspools and low rates of sewage collection $(24.9 \%)$ and treatment $(15.0 \%)$, with frequent bacterial contamination (ANA, 2009; 2017). In the present study, the total coliforms and E. coli counts were $\geq 1600 \mathrm{CFU} \mathrm{mL}^{-1}$ in all analyzed wells, corroborating the hypothesis that high nitrate levels are related to deficiency of basic sanitation. Poor construction of wells and inadequate disposal of garbage, animal waste and cesspools near the wells may also contribute to high nitrate levels (São Paulo, 2019). Environmental education and appropriate orientation of the population is necessary to avoid contamination of the water table.

The quantity of total dissolved solids (TDS) was above the maximum allowed level in $70 \%$ of the wells, and only wells P1, P2 and P5 presented acceptable levels (Figure 2). TDS values of the remaining wells were higher than those found by Correia Filho (2011) in other wells in Imperatriz. TDS are composed of inorganic salts, mainly calcium, magnesium, sodium, and potassium cations and carbonate, hydrogencarbonate, chloride, sulfate, and nitrate anions, and of small amounts of organic matter dissolved in water (WHO, 2003). The hardness of water is mainly due to the presence of calcium and magnesium ions (WHO, 2010), and considering that chloride and sulfate levels and hardness were low in these waters (Table 1), it can be assumed that other salts that do not contain calcium, magnesium, sulfates or chlorides may be present in significant quantities in this water.

Because of the results from bacterial counts, the water from all wells investigated in this study was unfit for human consumption, since total coliforms and E. coli must be absent in drinking water (Brasil, 2017). Considering CONAMA Resolution No. 357 of 2005, which classified natural waters and established their parameters and uses (Conama, 2005) the water from all the analyzed wells could not be used for vegetable irrigation, because water used for this activity must be classified as at least Class 2; however, due to E. coli levels and $\mathrm{pH}$, none of the wells in this study could be classified in this category. These waters could be used for animal intake and for irrigation of tree, cereal and forage crops if it could be classified at least as Class 3. However, pH below 6.0 prevents its inclusion in this category, as well as in Class 4.

\section{CONCLUSIONS}

The water from all wells presented inadequate levels of total coliforms, E. coli, $\mathrm{pH}$, and iron, being unsuitable for human consumption and possibly for animals. In addition, its use for 
vegetable irrigation is inappropriate because of acidic $\mathrm{pH}$ and bacterial contamination. The wells with the highest number of physicochemical inadequacies were P10 (6 inadequacies: $\mathrm{pH}$, iron, oils and greases, nitrite, nitrate and TDS), followed by two wells with 5 inadequacies: P1 $(\mathrm{pH}$, iron, oils and greases, nitrite and nitrate) and $\mathrm{P} 3(\mathrm{pH}$, iron, oils and greases, nitrite and TDS). Others presented 4 inadequacies, such as $\mathrm{P} 4$ (pH, iron, oils and greases and TDS), P7, $\mathrm{P} 8$ and $\mathrm{P} 9(\mathrm{pH}$, iron, nitrate and TDS) or 3 inadequacies, as $\mathrm{P} 5(\mathrm{pH}$, iron and nitrite) and P6 ( $\mathrm{pH}$, iron and TDS). The low water quality of these wells is a risk for contamination of the water table of the area and may contaminate other bodies of water at the time of discharge. Therefore, the origin of oils and greases should be better investigated, as well as the origin of the nitrates found in this study.

\section{REFERENCES}

ABDANUR, A.; NOLASCO, M. A. Remediação de água subterrânea contaminada com hidrocarbonetos em uma refinaria de óleo. Revista Acadêmica Ciência Animal, 3, n. 2, p. 47-53, 2005. http://dx.doi.org/10.7213/cienciaanimal.v3i2.9099

ABNT. NBR 10664: Waters - determination of residues (solids) - gravimetric method - method of test. Rio de Janeiro, 1989.

NBR 12619: Waters - determination of nitrite-sulfanilamide and N-(1-naftil) ethylenediamine methods - method of test. Rio de Janeiro, 1992a.

NBR 12620: Waters - Determination of nitrate - chromotropic acid and phenol disulfonic acid methods - method of test. Rio de Janeiro, 1992b.

. NBR 13934: Water - iron determination phenanthroline colorimetric method - method of test. Rio de Janeiro, 1997.

AGÊNCIA NACIONAL DE ÁGUAS (Brasil). Plano estratégico de recursos hídricos da bacia hidrográfica dos rios Tocantins e Araguaia: relatório síntese. Brasília, DF, 2009. $256 \mathrm{p}$.

Conjuntura dos recursos hídricos no Brasil 2017: relatório pleno. Brasília, DF, 2017. 169 p.

ALVES, L. M. C. Qualidade da água de múltiplos usos na microrregião de ItapecuruMirim-MA. 2010. 104 f. Doctoral dissertation (Doctor of Veterinary Medicine) Faculdade de Ciências Agrárias e Veterinárias, Universidade Estadual Paulista Julio de Mesquita Filho, Jaboticabal, 2010. Available at: http://hdl.handle.net/11449/103810.

APHA; AWWA; WEF. Standard Methods for the examination of water and wastewater. 23rd ed. Washington, 2017. 1504 p.

BRASIL. Ministério da Saúde. Portaria n. 05, de 28 de setembro de 2017. Consolidação das normas sobre as ações e os serviços de saúde do Sistema Único de Saúde. Diário Oficial [da] União: seção 1, Brasília, DF, n. 190, supl. p. 516-531, 03 de out. de 2017.

COELHO, S. C.; DUARTE, A. N.; AMARAL, L. S.; SANTOS, P. M. d.; SALLES, M. J.; SANTOS, J. A. A. d.; SOTERO-MARTINS, A. Monitoramento da água de poços como estratégia de avaliação sanitária em Comunidade Rural na Cidade de São Luís, MA,

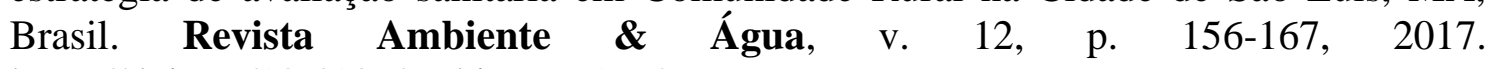
https://doi.org/10.4136/ambi-agua.1962. 
CONAMA (Brasil). Resolução n $^{\circ} 357$ de 17 de março de 2005. Dispõe sobre a classificação dos corpos de água e diretrizes ambientais para o seu enquadramento, bem como estabelece as condições e padrões de lançamento de efluentes, e dá outras providências. Diário Oficial [da] União: seção 1, Brasília, DF, n. 053, p. 58-63, 18 mar. 2005.

CORREIA FILHO, F. L. Projeto cadastro de fontes de abastecimento por água subterrânea, estado do Maranhão: relatório diagnóstico do município de Imperatriz. Teresina: CPRM, 2011. 42 p.

COSTA NETO, M. C. da; LOPES, E. C. d. S.; ANJOS, G. C. d.; MELO, A. F. F. d. Geologia e recursos minerais da folha Imperatriz SB. 23-VCV, estado do Maranhão, escala 1: 100.000. Belém: CPRM, 2014. 87 p.

DE OLIVEIRA, L. I.; LOUREIRO, C. d. O. Contaminação de aqüíferos por combustíveis orgânicos em Belo Horizonte: Avaliação preliminar. Águas subterrâneas, suppl., p. 1$10,1998$.

DE OLIVEIRA, T. W. da S.; DA SILVA, S. H. P.; SILVA, D. F.; VIANA, J. F. C.; FIRMO, W. de C. A.; SILVA, M. R. C. Aspecto da sazonalidade nos parâmetros físico-químicos da água dos poços, Raposa-Maranhão, Brasil. Águas Subterrâneas, v. 33, n. 2, p. 1-9, 2019. https://doi.org/10.14295/ras.v33i2.29517

FUNDAÇÃO NACIONAL DE SAÚDE (Brasil). Manual prático de análise de água. 2. ed. rev. ed. Brasília, DF, 2006. 146 p.

IBRAHIM, N. I. M. The relations between concentration of iron and the $\mathrm{pH}$ groundwater (case study Zulfi ground water). International Journal of Environmental Monitoring and Analysis, v. 4, n. 6, p. 140-145, 2016. https://doi.org/10.11648/j.ijema.20160406.11

ITYEL, D. Ground water: Dealing with iron contamination. Filtration \& Separation, v. 48, n. 1, p. 26-28, 2011. https://doi.org/10.1016/S0015-1882(11)70043-X

MARQUES, F. C.; CAVALCANTE, P. R. S.; BARBIERI, R. Qualidade das águas subterrâneas da área urbana no município de Santa Helena (MA). Águas Subterrâneas, supl., p. 1-12, 2010 .

OLIVEIRA, M. M. Análise físico-química e microbiológica de águas de poços artesianos de uso independente do município de Timbiras-Maranhão. Revista Gestão \& $\begin{array}{lllllll}\text { Sustentabilidade Ambiental, v. 7, n. 3, p. 624-639, } 2018 . & \text {. }\end{array}$ http://dx.doi.org/10.19177/rgsa.v7e32018624-639

PHILIPS, S.; LAANBROEK, H. J.; VERSTRAETE, W. Origin, causes and effects of increased nitrite concentrations in aquatic environments. Reviews in Environmental Science and Biotechnology, v. 1, n. 2, p. 115-141, 2002. https://doi.org/10.1023/A:1020892826575

RODRIGUES, J. B.; DA SILVA, D. D. S.; DE FREITAS, S. J. N.; CABRAL, A. C. L. C.; PFEIFF, G. K.; DE SOUSA AMORIM, I. L. Qualidade da água utilizada na irrigação de produtos orgânicos: o caso de um polo agrícola em Paço Lumiar/MA. Nature and Conservation, v. 13, n. 1, p. 16-21, 2020. https://doi.org/10.6008/CBPC23182881.2020.001.0003

SACCHI, E.; ACUTIS, M.; BARTOLI, M.; BRENNA, S.; DELCONTE, C. A.; LAINI, A.; PENNISI, M. Origin and fate of nitrates in groundwater from the central Po plain: Insights from isotopic investigations. Applied Geochemistry, v. 34, p. 164-180, 2013. https://doi.org/10.1016/j.apgeochem.2013.03.008 
SANTOS, I. B.; DA SILVA, M. M. S.; DA SILVA FILHO, F. P.; DE ARAÚJO SILVA, T. L. Análise da qualidade da água utilizada no consumo pelos pequenos ruminantes na zona rural do município de Imperatriz-MA. In: DA SILVA-MATOS, R. S.;DE OLIVEIRA, P. S. T. et al. (eds.). Ciências agrárias: conhecimentos científicos e técnicos e difusão de tecnologias 3. Ponta Grossa: Atena, 2020. cap. 3, p. 26-36.

SÃO PAUlO. Conselho Estadual de Recursos Hídricos. Câmara Técnica de Águas Subterrâneas. Nitrato nas águas subterrâneas: desafios frente ao panorama atual. São Paulo: Secretaria de Infraestrutura e Meio Ambiente; Instituto Geológico, 2019. 128 p.

TABATABAI, M. A. A rapid method for determination of sulfate in water samples. $\begin{array}{llllllll}\text { Environmental Letters, } & \text { v. } 7, \quad \text { n. } & \text { 3, p. 237-243, } & 1974 .\end{array}$ https://doi.org/10.1080/00139307409437403

TACK, F. M.; CALLEWAERT, O. W. J. J.; VERLOO, M. G. Metal solubility as a function of $\mathrm{pH}$ in a contaminated, dredged sediment affected by oxidation. Environmental Pollution, v. 91, n. 2, p. 199-208, 1996. https://doi.org/10.1016/0269-7491(95)00049-6

VAN DER GUN, J. The Global Groundwater Revolution. In: SHUGART, H. (ed.). Oxford Research Encyclopedia of Environmental Science. Oxford: Oxford University press, 2019. https://doi.org/10.1093/acrefore/9780199389414.013.632.

WARD, M. H.; JONES, R. R.; BRENDER, J. D.; DE KOK, T. M.; WEYER, P. J.; NOLAN, B. T.; VILLANUEVA, C. M.; VAN BREDA, S. G. Drinking Water Nitrate and Human Health: An Updated Review. International Journal of Environmental Research and Public Health, v. 15, n. 7, p. 1557, 2018. https://doi.org/10.3390/ijerph15071557

WHO. Total dissolved solids in drinking-water: background document for development of WHO guidelines for drinking-water quality. Geneva, 2003.

Hardness in drinking-water: background document for development of WHO guidelines for drinking-water quality. Geneva, 2010.

ZHAI, Y.; ZHAO, X.; TENG, Y.; LI, X.; ZHANG, J.; WU, J.; ZUO, R. Groundwater nitrate pollution and human health risk assessment by using HHRA model in an agricultural area, NE China. Ecotoxicology and Environmental Safety, v. 137, p. 130-142, 2017. https://doi.org/10.1016/j.ecoenv.2016.11.010 